\title{
Comparative Urbanism: New geographies and cultures of theorising the urban
}

\author{
Jennifer Robinson \\ Department of Geography \\ University College London
}

26 Bedford Way

London

WC1H OAP

Jennifer.Robinson@ucl.ac.uk

\begin{abstract}
In response to the growing interest in ways to take forward an agenda for a more global urban studies this paper advocates a comparative approach to theory building which can help to develop new understandings of the expanding and diverse world of cities and urbanisation processes, building theory from different contexts, resonating with a diversity of urban outcomes but being respectful of the limits of always located insights. The paper is inspired by the potential of the comparative imagination but, mindful of the limitations of formal comparative methods, which in a quasi-scientific format can drastically restrict the scope of comparing, it outlines ways to reformat comparative methods in order to put it to work more effectively for a more global urban studies. The paper proposes a new typology for comparative methods based on the vernacular practices of urban comparison, tracing these through the archives of comparative urbanism. It also suggests some lines of philosophical reflection for reframing the scope and style of theorising. New repertoires of comparativism are indicated which support the possibility of a revisable urban theory, starting from anywhere.
\end{abstract}

Keywords: Comparative urbanism, urban theory, methods, theory cultures.

A growing number of voices express an eagerness to develop new practices of global urban theorising and generate new concepts for thinking 21st Century cities (Parnell, 1997; 
Simone, 2001; Robinson, 2006; Parnell, Pieterse and Watson, 2009; Roy, 2009; Wu, 2010 Simone, 2011a; Chen and Kanna, 2012; Edensor and Jayne, 2012). As the contemporary economic and geopolitical shift of resources and power relations redefines the global geography of investment in scholarly resources and as urbanisation trends displace the former heartlands of urban theory, urban studies will produce a new generation of scholarship which arises in new centres of authority and expertise, and which is inspired by a very different repertoire of cities and ideas from those which shaped twentieth century urban theory.

A variety of possible ways of taking forward this agenda proliferate in the field, from ethnographically-inspired theorisation (Simone, 2011b) to embracing new analytical and methodological agendas (Jacobs, 2006; Farinas and Bender, 2010; McFarlane, 2011), building regionally-inspired insights (Watson, 2009; Hsing, 2010; Roy and Ong, 2011; Bunnell, 2013; Pieterse, 2013; Parnell and Olfield, 2014), refitting political economy approaches (Peck, Theodore, Brenner, 2009; MacLeod, 2011) as well as methodological innovations in comparative urbanism (Ward, 2010; McFarlane, 2010; Robinson, 2011) and reviving some of the core analytical and philosophical puzzles associated with defining the urban to reconfigure the conceptual geographies of the urban at a planetary scale (Lefebvre, 2003; Merrifield, 2013; Brenner and Schmid, 2014). Moreover there is an outpouring of exciting research being submitted to IJURR and to other urban studies journals in recent years, exploring a wide array of conceptual issues and urbanisation processes in relation to cities from around the world. While it is hard to see how this tide of theoretical innovation can be turned around (or why, indeed, it should?) it is also clear that there are concerns amongst some scholars that the growing post-colonial and global urban theoretical agenda displaces earlier dominant approaches, or renders parochial and limited previously ambitious and universalising theoretical agendas (Smith, 2014; Scott and Storper, 2014).

In the search for new ways to do a more global urban studies, at stake are the scope and starting points as well as the cultures of theorising. There is agreement that new ideas might arrive from different contexts and disturb wider theorisations (Scott and Storper, 2014, p. 28). It is essential though that the terms of theorisation are not pre-set, which, disappointingly, is the recommendation of Scott and Storper - that we can theorise but only 
using already-given concepts (a proposition which long ago drew a derisory response from Partha Chatterjee (1993) who wondered what, then, was left to think?). So I would suggest that there are important issues to debate concerning the cultures of theorising which would facilitate a more global urban analysis: can we promote theory cultures which are alert to their own locatedness and sources of inspiration, open to learning from elsewhere, respectful of different scholarly traditions, and committed to the revisability of theoretical ideas. At stake too are the geographies of theorising. Being open to ideas from elsewhere, while attending to the locatedness of all conceptualisation, raises challenging questions about the specificity or limited scope of some concepts, and about the extent to which it is productive to think with ideas across many different experiences - at the limit, to propose a universal theory of urbanisation. Conversely, we need to be alert to the ways in which the differentiated grounds for speaking into wider theoretical conversations are framed. These can certainly be productive and engender distinctive conceptualisations, but might also potentially reinstate incommensurabilities between different kinds of contexts. Thus whether these are imagined as "regions" (see Roy, 2011 and Bunnell, 2013 for a critique of this), continents (Mbembe and Nuttall, 2004) or the invented geopolitical concept of the global South (Parnell and Oldfield, 2014; Robinson, 2014a), the imagined geographies of new subjects of theorisation also demand our critical attention.

In this paper I set out a summary response to these questions: How might a more global urban studies be grounded, methodologically and conceptually? How might we work productively with existing theories while keeping conceptualisation open to inspiration from any city? Can we encourage a culture of theoretical practice commensurate with the revisability of concepts, respectful of divergences and differences? How might we provide a rigorous foundation for the possibility of beginning conceptualisation anywhere?

The approach I signpost here takes inspiration from comparative urbanism's openness to conceptual revision, and offers methodological and philosophical grounds for a new repertoire of comparative methods open to "thinking with elsewhere". Such an approach would mobilise the potential to start conceptualisation from any city and to draw insights from a wide array of contexts which acknowledging the locatedness of all theoretical endeavour. New concepts might then be initiated from anywhere, and inherited 
conversations about the nature of the urban refined or refused. I stress the need to reconfigure the conventions surrounding the determination of the "third term" of comparison (Jacobs, 2012), which provides the grounds for thinking across different cases. Based on comparative practice, rather than formal methodological requirements, I suggest that this can helpfully focus on finding shared features across cases, or working with "repeated instances" (Jacobs, 2006) distributed across numerous urban contexts and produced within shared and interconnected processes. Thinking with variation and repetition, rather than trying to "control for difference", I am inspired by the comparative commitment to a creative theoretical practice focussed on the revisability of inherited (and located) understandings. I suggest that the theory-building tactics of composing comparisons or designing "natural experiments" by following the numerous interconnections and repeated instances across and amongst cities hold out much promise for creating new cultures and geographies of theorising, which could help with the work of generating a more global urban studies. In the array of experimental and inventive comparative practices for conceptual innovation which increasingly characterise the field of urban studies, as well as in the archives of vernacular comparative urban practices, the potential for contributing to crafting a more global urban studies is evident.

\section{Ways to go global: in the archives of comparative urbanism}

Urban studies' enthusiasm for understanding cities in a world of cities is very longstanding much more so than a quick critique of contemporary postcolonial analyses might allow: current critics stand on very broad shoulders. In fact, debates about "world" urbanism and attending to analyses of cities from around the world (Ginsburg, 1955; Southall, 1973; Parnell, 1997) speak to an important and ongoing desire within urban studies to think the urban through the diversity of urban experiences. I build my argument about the potential of comparative urbanism initially in this section through this archive, reaching back to some relatively familiar materials, then, in order to demonstrate that the dilemmas of thinking across diverse and divergent urban contexts, and the search for ways to conceptualise across those differences, to generate more global understandings of the urban, are already 
deeply embedded in the canon of urban studies. (A fuller discussion can be found in my introduction to an IJURR virtual issue on Comparative Urbanism.)

In arguably the first wave of comparative urbanism, Louis Wirth (1938) incited a vast literature exploring the consequences of his theoretical claims for different cities. So while Wirth certainly erred on the side of universalising ambition, those who engaged with his work around the world (and at home in the US) critiqued many elements of his analysis drawing on their particular case studies. My favourite examples, which I discussed at length in Ordinary Cities, saw urbanists working in Southern Africa draw on the resonances they found there with the Chicago experiences (now well disclosed as the particular inspiration for the more ambitious theories of Wirth), such as large-scale and diverse migration, and a recent transition to industrial and urban employment. With the keen eyes of anthropologists writers like Max Gluckman (1961) and Clyde Mitchell (1987), as well as colleagues in many other parts of the world, quickly discounted Wirth's assumption that the combination of heterogeneity and industrialisation would confirm Simmel's hypothesis that urban social relations would become distantiated and encourage a blasé attitude, or lead to the throwing off of folk traditions.

Far from it being "wrong" or somewhat foolish to imagine applying such a theory to the Zambian copperbelt (as Scott and Storper (2014) rather mischieviously misinterpret me as suggesting), through their critical encounters with Wirth those anthropologists offered much that was worth thinking with - as numerous urban scholars found, and indeed for many decades after the work was published (e.g. Granovetter, 1973; Fischer, 1975)! I have expressed my disappointment that these early debates and comparative experiments in globalising urban theory were discarded and disappeared from the canon of an urban theory increasingly divided between analyses of wealthier and poorer cities in the wake of developmentalism (Robinson, 2006). Nonetheless, they remain as a fascinating record of the vitality of thinking across the diversity of urban outcomes, and expose a seam of urban theory which drew inspiration from a very wide range of different urban experiences.

Just as these debates on urban ways of life had consolidated a more global perspective on urban theory, a new theory revolution initiated what is still in many ways the current 
horizon of interpretation in urban studies - Marxist analyses of the global political economy or, at that time following Immanuel Wallerstein, the world-economy. Here the archives of comparative experiments highlight a new way of thinking across the world of cities.

Whereas the anthropologists had engaged with Wirth based on shared features (migration; industrialisation) in diverse and distant cities, the world-economy focus brought in a new way to think cities together - through their interconnectedness. Concerned that early Marxist urban theory was developing with insufficient reference to the experiences of cities around the world, David Slater observed in 1978 that

\footnotetext{
"although it is certainly the case that in the last few years the theoretical analysis of capitalist urbanization has progressed considerably ... much of this progress has been rooted in the experiences of the advanced capitalist economies" (p. 27).
}

There followed a range of interesting comparative experiments exploring how the interdependent dynamics of the world-economy made it essential to think cities in wealthier contexts (metropoles) in the same analytical frame as those of poorer economies (peripheries). The nature and form of extraverted political relations, or the kinds of transnational economic circuits which defined growth paths and shaped urban development were brought into view and traced across the globe (Lubeck and Walton, 1979; Slater, 1978).

These two comparative practices - thinking with shared features and variation across different cities; and drawing cities around the world into analytical juxtaposition through their interconnectedness - were both important in Friedmann and Wolff's (1982) seminal article in which they extended earlier descriptive accounts of world cities (Hall, 1966) to propose that a global network of cities played an important role in articulating the world economy. They argued, provocatively, that world cities might include, for example, "Tokyo, Los Angeles, San Francisco, Miami, New York, London, Paris, Randstadt, Frankfurt, Zurich, Cairo, Bangkok, Singapore, Hong Kong, Mexico City and São Paulo". Further, they indicated that, 
"What makes this typology attractive is the assumption that cities situated in any of the three world regions will tend to have significant features in common" (p. 311).

In the now well-known story, world cities, with many shared features (including economic restructuring, informality, inequality, citadels and slums, and often strong political contestation) were to be found in core and semi-peripheral parts of the world and were both shaped by and in turn shaped the economic, political and ideological processes of the capitalist world-economy. Their roles were not simply functionally determined, but emerged through political action and contestation. Framing their approach, and crucial for how urban studies scholars today approach global urbanisation, was the observation that while Marxist analyses of the city had criticised the class relations shaping urban production under capitalism, they had not made the links with the wider processes shaping the worldeconomy. They drew on the world systems perspective to explore how world cities are key points of spatial articulation of the world-economy:

"The critical variable in the study of particular world city regions is their mode of integration with the world economy" (p. 329).

Since this intervention, urban studies has not looked back: the global processes constituting and being constituted by urbanisation and urban outcomes are widely seen as essential to understanding any city (Massey, Allen and Pile, 1999; McCann and Ward, 2010)i. However, at the same time that this and subsequent world and global cities interventions opened up the world of cities to investigation at a global scale, they also systematically set bounds to comparability on the basis of the limited scope of the specific theoretical object of study, meaning that the opportunity to study a wide swath of cities across the semi-periphery and centre of the world economy on the same terms was quickly undercut by a stronger focus on a very small number of "global" cities or a set of "global city functions" a little more widely distributed (Sassen, 1994) or the somewhat more dispersed, but analytically rather narrow, form of a range of advanced producer service activities seen as important to coordinating the global economy (Taylor, 2004). Critics and advocates alike have drawn a variety of different urban contexts into conversation with this productive theoretical 
endeavour (e.g. Shatkin, 1998; Hill and Kim, 2000; the GAWC website stands as a fascinating archive of this work - www. lboro.ac.uk/gawc). But the rich critical potential of this approach to more fundamentally decentre urban studies - on this see especially Anthony King's important work placing colonial cities in the same category as world cities $(1989,1990)$ - lost purchase on the backs of policy and analytical interest in the special class of "Global City" or the relatively narrow specification of the processes and characteristics distinctive to world cities (Robinson, 2006).

Alongside these theoretically-driven trends in thinking different cities together in an interconnected global economy, urbanists have found many moments when a more deliberately composed comparative perspective seemed helpful to advancing understanding of urban processes. This includes Castell's $(1976 ; 1983)$ explorations of urban social movements across quite a diverse array of urban contexts (Santiago de Chile, Madrid, Glasgow, Paris, San Francisco), or Susan Clarke's (1995) exemplary comparison of local government responses to economic restructuring across the US, or Hank Savitch and Paul Kantor's (2004) innovative analysis of urban regimes across 10 US-Canadian and European cities, or more macro-theoretically driven reflections across western and socialist contexts (Murray and Szelenyi, 1984; Kennedy and Smith, 1983). The opportunity to think cities through elsewhere has generally drawn on shared features of cities to stimulate creative theorisation across diverse outcomes. Savitch and Kantor (2004), for example, observe that exploring "variation" across cases is the effective site of conceptualisation (see also Wacquant, 2009, on Weberian inspirations for conceptualising with variation). They note that

"our cities have been chosen because they illustrate a broad range of variation on variables that we believe are critical to urban development politics" (p. 2324).

However, as I have argued elsewhere (Robinson, 2011), in the case of variation-finding studies the strictures of inherited research methods have strongly limited the range of cities drawn into such comparative reflections. 
Thus while the potential to draw cities across the world into a shared analytical frame has long been established, in relation to thinking with interconnections amongst cities, or with the shared features across different urban contexts, both sets of practices have been limited in terms of the range of cities admitted to comparative reflection.

But with the renewed postcolonial critique in urban studies the potential to think with the diversity of urban outcomes within and across cities is now well established (as the contributions to this symposium indicate). Indeed the desire to think for all cities everywhere (as Scott and Storper, 2014, explicitly articulate, and as much urban theory implicitly assumes) is precisely to enter into this terrain - and to urgently demand some methodological clarity on what it might mean to think cities in a world of cities: how theorising the urban "now" (Robinson, 2013) might fruitfully proceed.

\section{Revisable theory}

The shift in the geographical centre of global urbanisation, the diversity of forms of urban settlement, as well as the increasingly world-wide impacts of urbanisation processes, have led many urbanists to propose a renewal, if not a fundamental transformation, in urban theory (Parnell et al., 2009; Roy and Ong, 2011; Merrifield, 2013; Brenner and Schmid, 2014). Brenner and Schmid (2014) propose that this is a moment to confront head on the impossible object of the city, whose boundaries are perhaps even more indistinct than ever, suggesting that this traditional object of urban studies is arguably disappearing in the face of "planetary" urbanisation processes. Moreover, new theoretical optics, such as Actor Network Theory, also impress the need for new thinking on the nature of the urban (see Farias and Bender, 2010; McFarlane, 2011).

Furthermore, the world of scholarly production on cities is changing rapidly. The growing output from Asian scholars documenting and thinking through the extraordinary growth of cities there, in the context of a spatially fragmented developmental state, expansion-fuelling incentives to local government officials to develop urban areas, and a geopolitically ambitious national project of global presencing, has already created a new centre for urban 
theoretical reflection (Lin, 1999; Wu, 2004, 2010; Hsing, 2010; Ren, 2012). However, while the editors of this journal, for example, report a growing proportion of submissions from scholars based in or writing about this region, rejection rates are highest for papers submitted by scholars based outside of northern and western institutional contexts (Boudreau and Kaika, 2013). One important reason for this lies in the expectations generated by the "theory culture" of critical urban studies. It is a disappointing outcome indeed if the terms of widening the scope of debates in urban studies are that scholars are forced to engage with sometimes not very relevant western analytical concepts in order to find international publication outlets. Nonetheless, the potential for a careful analytical engagement across different contexts to bring emergent processes shaping Chinese cities into comparative reflection is well demonstrated by Wu $(2004 ; 2010)$, for example, and directly endorsed by Friedmann's (2006) review of debates in Chinese urbanism for nonSinologists (see also Lin, 1999; Liu, 2012). Sue Parnell and Edgar Pieterse's (2014) article in this volume discusses similar concerns in relation to new centres of writing on cities in Africa, where the opportunities and need for emergent theorisation as well as foundational empirical research are also strong (see also Myers, 2011). There is an urgent need in urban studies to build cultures of theorising which appreciate and foster a diversity of theoretical starting points.

In this light, asserting the importance of preserving an existing general theorisation - albeit one which has been valued and productive in many contexts - is highly problematic. Processes such as urban agglomeration economies or urban land markets, suggested by Scott and Storper (2014) as the basis for a universal account of the "nature of cities", for example, might seem at first sight to offer productive starting points for thinking across a world of cities. However, the extant literature on these topics already indicates some important disjunctures and reasons to think again about what shapes cities. Starting somewhere else exposes the parochial elements of these inherited perspectives.

Attention needs to be paid, for example, to some of the largest cities in the world where logics of agglomeration associated with capitalist accumulation arrive on the urban scene long after residents have generated urban life as a platform for reproducing their bodies, sheltering their families and servicing their neighbourhoods (Bryceson, 2006 develops an 
excellent account of African urban economies from this baseline of reproduction). This could be a prompt to scholars in less poor cities to recall the feminist critiques pointing out the work of reproduction which grounds the economic agglomeration potential of all cities, including London, for example, where the tensions of reproducing life under the strong agglomeration pressures of the global finance and services sectors are evident (see also the work of Gibson-Graham, 1996) $)^{i i}$. There is certainly evidence that urbanisation does not necessarily support economic vitality (Bryceson, 2014; Turok, 2014) or even at times human reproduction (de Boeck and Plissart, 2004). Furthermore, the logics of agglomeration which drive some retail and industrial clusters in situations of informality and poverty actively undermine the potential for expansion, innovation and initiative (McCormick, 1999).

Perhaps more graphically, the limits to extant theorisations of land markets are evident from the extensive critical literature on land title registration initiatives across cities in Africa and elsewhere, inspired by Hernando de Soto's stringent policy advice. The diversity of ownership forms in a vast number of cities, including traditional, collective, informal, illegal and public ownership, as well as peremptory violent appropriation to advance territorial political agendas (and war), mean that any theorisation of urban land needs to be willing to think again about starting points and to delimit the scope of located conceptualisations (Payne et al., 2007; Myers, 2008; Marx, 2009; Earle, 2013; Hasan et al., 2013).

Certainly there is much traffic in concepts and ideas around the world, and many concepts or theories (from wherever) are good to think with and can generate productive insights in settings beyond those which shaped their conception, or even beyond their reasonable sellby date (as with the return to Wirth in the 1990s). Turok's (2014) policy-oriented review of African urban economic development, for example, draws on analyses of agglomeration economies to consider how planning and infrastructure interventions might enable cities across the continent to more effectively support growth. However, the extraordinary challenge of establishing a universally valid theory in the face of a great diversity of urban outcomes as well as the pragmatics of a postcolonial theoretical context where it is inappropriate to treat some places and some scholarship as purely data fodder for existing theories - a point Connell (2007) makes very well - mean that the geographical scope and cultures of urban theorising need to be rethought. The diversity of urban contexts with local 
and visiting scholars eager to interpret and probe their meaning, and the rapidly changing structure of global urbanisation, mean that any theorisation of the urban for the $21^{\text {st }}$ century has to be open to criticism, contestation, extension, stretching - and indeed, stretching to the breaking point at which it is clear something new is required (the wager, perhaps, of both the postcolonial and the Planetary Urbanisation critiques).

We may well be living, then, in a moment when there could be a need for a radical break in theoretical endeavours around the urban iii. But more prosaically, and most especially in a field whose object is quite so differentiated as the urban, theorising has as a fundamental requirement the need to be willing to think again (and even start again) in the light of new experiences and evidence. What kinds of theoretical practice might support this?

\section{New Repertoires of comparative urbanism}

This is the starting point for my enthusiasm for comparative urbanism. It begins with the ambition to test, and to change, theoretical propositions. It has a great track record of inventing new concepts, and has something to teach urban scholars about how it might be possible to bring different kinds of urban contexts together into the same analytical frame and to think with insights from elsewhere: which we currently have many reasons and opportunities to do. The imperative for revisable theory generation is at the heart of comparative urbanism, then, as is the commitment to theory as enabling conversations beyond the single case (Connell, 2007). It exposes the possibility of real theoretical breaks in understanding specific topics while also provoking a framework for wider conversations.

Thus comparative urbanism might help to develop new approaches to understanding an expanding and diverse urban world, building theory from many different starting points, perhaps resonating with a range of different urban outcomes but being respectful of the limits of always located insights. As I have turned to consider this I have been both inspired by the potential of the comparative imagination but also mindful of the limits which have been placed on its scope not only by inherited assumptions of urban theory, but also by a quasi-scientific methodological formulation (Robinson, 2011). I have therefore been drawn 
to an exercise in reformatting comparative methods and ontology in order to put it to work more effectively for a more global urban studies. Thus I have found it helpful to pare comparison back to its core assumptions. This also has the effect of significantly expanding the repertoire for comparative tactics beyond the conventional variation-finding or the more innovative encompassing methods prominent in urban studies (Tilly, 1984; Pickvance, 1986; McMichael, 1990; Brenner, 2001; Kantor and Savitch, 2005), effectively putting the light touch "comparative gesture" at the heart of the field to a more precise use. Counter to the ambitious scope and sometimes dominating authorial voice of a universalising theoretical practice, eager to draw "elsewhere" in as evidence to support existing analytical agendas, a reformatted comparativism proposes an agile theoretical practice, certainly eager to engage with existing conceptualisations, but committed to revisability, to thinking through a diversity of urban outcomes and to being open to starting to theorise from anywhere.

A very important analytical change in defining a new repertoire of comparative practice is to abandon the hopeless effort to apply a quasi-scientific rigour to case selection based on attempting to control for difference across cities. In many urban comparative studies to date it is precisely the variation across the cases that has provided the grounds for conceptual innovation and invention. In this way comparative practices can be developed for enriching conceptualisations of urban processes through addressing a greater diversity of urban outcomes while remaining rigorous and plausible. The rather narrow grounds for case selection based on unnecessary concerns with "controlling for variation" at the city scale has to date supported the exploration of relatively limited set of parochial theoretical concepts (perhaps most famously in the case of urban regime theory); a much broader range of conceptualisations can be put into play for comparative exploration by focussing on the shared experiences of cities around the world. There is great potential for internationalising regime theory, for example, by attending to a stronger role for transnational actors in urban development politics (e.g. in relation to Mumbai and Delhi see Harris, N., 1995; Harris, A., 2008; Ghertner, 2011) and exploring the informality of governance arrangements characterising both government institutions and their external partnerships in many different contexts (Lowndes, 1996; Gordon, 2003; Borraz and Le Galès, 2010). 
The practical and analytical questions as to whether there are some bounds to how far concepts can be useful to interrogate different cases remain. Importantly, these will not be pre-given, and should themselves be the subject of careful investigation. Attention to these limits, and to the complexities of translating concepts and phenomena across contexts is crucial (Savitch and Kantor, 2005; McFarlane, 2010; Jazeel, 2014); but so is keeping open the possibility for all cities to potentially inform theoretical innovation in urban studies. This reaffirms the wider point that theorising in comparative mode is necessarily partial, open to multiple starting points, and concerned to assess its own limits. It is my personal hope that such a commitment to theoretical revisability will inspire the cultivation and performance of modest and respectful theorising subjects, open to critique and attentive to their own limitations (see also Bunnell and Maringanti, 2010; Peake, this volume).

Rather than controlling for difference, restricting analyses to most similar cities, we can turn the traditional methodological advice around and indicate that finding shared processes or outcomes forms a good basis for comparing, in the context of which analysis of the proliferation of difference is good for creative thinking about the determination of that phenomenon. Assembling a comparator (Guggenheim et al., 2015) or opening up the grounds for constituting the third term bringing cases into conversation (Jacobs, 2012) becomes a site for inventive and positive experimentation, drawing on the many opportunities for making connections with elsewhere which cities generate. Inspired by Deleuze (1994), I suggest that urban comparisons might be thought of as "genetic", tracing the interconnected genesis of repeated, related but distinctive, urban outcomes as the basis for comparison; or as "generative" where variation across shared features provides a basis for generating conceptual insights supported by the multiple, sometimes interconnected, theoretical conversations which enable global urban studies (Robinson, forthcoming ).

In some ways, then, we need to begin again with thinking about comparison in relation to the urban. Paring it back to its minimalist components, I have come to think of comparison as a wide-ranging set of practices for "thinking (cities) through elsewhere" which bring different cases together in either composed or natural experiments to inspire conceptualisation. In developing some new repertoires of comparison I have found it 
helpful to work with actual practices in urban studies (as opposed to quasi-scientific formal methodological requirements) and to build on the specific spatiality of the urban, notably the overlapping interconnections amongst cities which shape both distinctive but often shared and repeated outcomes. Thus new taxonomies of urban comparisons become visible which can be (and have been) put to work for a more global urban studies: building comparisons through putting case studies into wider conversations - where case studies do not need to be defined territorially but might be any kind of urban process or outcome, for example, projects or events or even the flows and connections amongst cities (Peck and Theodore, 2012; Söderström, 2014). Thus we can imagine, composing bespoke comparisons across shared features or "repeated instances"; tracing connections amongst cities to inform understandings of different outcomes or to compare the wider interconnections and extended urbanization processes themselves; and launching distinctive analyses from specific urban contexts or regions into wider theoretical conversations ${ }^{i v}$. Table 1 shows examples of such practices bringing cities together for analytical reflection from many different parts of the world, including Africa (cf. Parnell and Pieterse, this volume), and demonstrates well the potential of a comparative imagination to support a more global urban studies (for a fuller discussion, see Robinson, forthcoming). 


\section{TABLE ONE}

\begin{tabular}{|c|c|c|}
\hline $\begin{array}{l}\text { Type of } \\
\text { Comparison }\end{array}$ & Features & Examples \\
\hline $\begin{array}{l}\text { The comparative } \\
\text { gesture }\end{array}$ & $\begin{array}{l}\text { Light touch } \\
\text { referencing to } \\
\text { different urban } \\
\text { contexts }\end{array}$ & Ubiquitous \\
\hline $\begin{array}{l}\text { Cases in wider } \\
\text { conversations }\end{array}$ & $\begin{array}{l}\text { Detailed case studies } \\
\text { with theoretical } \\
\text { implications }\end{array}$ & $\begin{array}{l}\text { Numerous: e.g. Simone (2001); Arabindoo } \\
\text { (2013); de Boeck and Plissart (2004) }\end{array}$ \\
\hline \multirow[t]{3}{*}{$\begin{array}{l}\text { Composing } \\
\text { comparisons }\end{array}$} & $\begin{array}{l}\text { Designing bespoke } \\
\text { projects grounded in } \\
\text { shared features, } \\
\text { most similar/most } \\
\text { different distinction } \\
\text { not pertinent. }\end{array}$ & $\begin{array}{l}\text { Jacobs (1996); Simone (2011); Yiftachel (2009); } \\
\text { Wirth and Jones (1978); Huchzermeyer (2011); } \\
\text { Grant and Nijman (2004); Goldfrank and } \\
\text { Schrank(2009); Becker et al., 2013); Waley } \\
\text { (2012); Salskov-Iversen et al. (2001); Le Gales } \\
\text { and Borraz (2010); Vogel et al. (2009); Fourchard } \\
\text { and Simon (2012) }\end{array}$ \\
\hline & $\begin{array}{l}\text { Repeated instances: } \\
\text { urban phenomena } \\
\text { with shared } \\
\text { conditions of } \\
\text { production }\end{array}$ & $\begin{array}{l}\text { Jacobs (2006) residential high-rises; Dick and } \\
\text { Rimmer (2008) gated communities; Carpenter } \\
\text { and Lees (1995), Harris (2008), Lees (2012), Lees, } \\
\text { Lopez and Shin (forthcoming) gentrification; Keil } \\
\text { (2013) suburbs. }\end{array}$ \\
\hline & $\begin{array}{l}\text { Unexpected } \\
\text { comparisons }\end{array}$ & Roy (2003); Nijman (2007); Myers (2014) \\
\hline \multirow[t]{2}{*}{$\begin{array}{l}\text { Tracing } \\
\text { connections }\end{array}$} & $\begin{array}{l}\text { Circulating practices } \\
\text { leading to direct } \\
\text { comparative } \\
\text { reflections }\end{array}$ & $\begin{array}{l}\text { Ward (2006); Hart (2003); Theodore (2007); Peck } \\
\text { and Theodore (2012); Ndjio (2009); Lowry and } \\
\text { McCann (2011); Roy and Ong (2011) }\end{array}$ \\
\hline & $\begin{array}{l}\text { Comparing } \\
\text { connections }\end{array}$ & $\begin{array}{l}\text { Olds (2001); Peck and Theodore (2010); } \\
\text { Söderström (2014) }\end{array}$ \\
\hline Launching analyses & $\begin{array}{l}\text { Generating concepts } \\
\text { in specific contexts, } \\
\text { with possible wider } \\
\text { applications }\end{array}$ & $\begin{array}{l}\text { Informality: Simone (2001, 2011); Roy (2005) and } \\
\text { Benjamin (2008); LeGales (2010); insights from } \\
\text { development practice: Pieterse (2013); Parnell } \\
\text { and Robinson (2012). }\end{array}$ \\
\hline $\begin{array}{l}\text { The limits of } \\
\text { translation }\end{array}$ & $\begin{array}{l}\text { Sui generis outcomes; } \\
\text { distinctive meanings }\end{array}$ & $\begin{array}{l}\text { McFarlane (2010), Jazeel (2014) on } \\
\text { untranslatability; Watson (2009) on Southern } \\
\text { Urbanism. }\end{array}$ \\
\hline
\end{tabular}


Some remaining difficulties with making theory light and revisable rather than saturated with weighty and ambitious authorising voices are embedded deep in the ontology of comparative methods. How we understand "cases" and "theories" and their relationship raises some long-standing philosophical puzzles, such as the relation between the concrete and the abstract, or the particular and the universal, which bear on the potential of the case (in fact perhaps better considered as a singularity) to inform and transform, and not simply reproduce, existing conceptualisations (see Chaudhury, 2012; Robinson, 2014a; Stanek, 2008 has a useful discussion of these terms). I discuss this at some length in Robinson (forthcoming).

A vital and urgent consequence of any new geography of theorising - comparative or otherwise - should be that the mode and style of urban theorisation itself is transformed from an authoritative voice emanating from some putative centre of urban scholarship to a celebration of the conversations opened up amongst the many subjects of urban theoretical endeavour in cities around the world, valorising more provisional, modest and revisable claims about the nature of the urban. To achieve this requires not only methodological innovation, but also an open and respectful culture of theory production in urban studies. Moreover, It requires, as Parnell and Pieterse insist in their contribution, strong efforts to work against the destructive consequences of the deeply uneven material bases of global urban scholarship.

\section{References}

Arabindoo, P. (2011) 'City of sand': Stately re-imagination of Marina Beach in Chennai. International Journal of Urban and Regional Research, 35(2), 379-401

Becker, J., Klingan, K., Lanz, S. and Wildner, K. (Eds.) (2013) Global Prayers: Contemporary Manifestations of the Religious in the City, Lars Mueller Publishers, Zurich

Benjamin, S. (2008), Occupancy Urbanism: Radicalizing Politics and Economy beyond Policy and Programs. International Journal of Urban and Regional Research, 32: 719-729. 
Borraz, O. and Le Galès, P. 2010. Urban Governance in Europe : The Governance of What ? Pôle Sud, 32: 137-151.

Boudreau, J.-A. and Kaika, M. (2013), Reflections on the Academic and Economic Environment. International Journal of Urban and Regional Research, 37: i-v.

Brenner, N. 2001. World City Theory, Globalization and the Comparative-Historical Method: Reflections on Janet Abu-Lughod's Interpretation of Contemporary Urban Restructuring. Urban Affairs Review, September, pgs 124-147.

Brenner and Schmid (2014). The 'Urban Age' in Question. Forthcoming, International Journal of Urban and Regional Research. 38, 3: 731-755.

Bryceson, D. 2006. African Urban Economies: Searching for Sources of Sustenance, in D. Bryceson and D. Potts (Eds) African Urban Economies: Viability, Vitality or Vitiation? London: Palgrave Macmillan

Bryceson, D. (2014). 'Re-evaluating the Influence of Urban Agglomeration in Sub-Saharan Africa: Population Density, Technological Innovation and Productivity', in Parnell, S. \& S. Oldfield (eds) The Routledge Handbook on Cities of the Global South, London, Routledge, 206-18

Bunnell, T. (2013) 'City networks as alternative geographies of Southeast Asia', TRaNS: Trans-Regional and-National Studies,1(1): 27-43.

Bunnell, T. and Maringanti, A. (2010), Practising Urban and Regional Research beyond Metrocentricity. International Journal of Urban and Regional Research, 34: 415-420.

Carpenter, J. and Lees, L. (1995), Gentrification in New York, London and Paris: An International Comparison. International Journal of Urban and Regional Research, 19: 286303. 
Castells, M. 1979 The Urban Question: A Marxist Approach. Cambridge: MIT Press.

Castells, M. 1983. The City and the Grassroots. Oxford: Blackwells

Chatterjee, P. 1993. The Nation and Its Fragments: Colonial and Postcolonial Histories.

Princeton: Princeton University Press

Chen, X. and Kanna, A. 2012. Rethinking Global Urbanism: Comparative Insights from Secondary Cities. London: Routledge.

Clarke, S. E. (1995), Institutional Logics and Local Economic Development: A Comparative Analysis of Eight American Cities. International Journal of Urban and Regional Research, 19: 513-533.

Connell, R. (2007). Southern Theory: The global dynamics of knowledge in social science. Cambridge: Polity Press.

De Boeck, F. and Plissart, M-F. (2004). Kinshasa: Tales of the Invisible City. Ludion Press

Deleuze, G. (1994) Difference and Repetition, New York: Columbia University Press.

Dick, H.W. and Rimmer, P.J. 1998. Beyond the Third World City: The New Urban Geography of Southeast Asia. Urban Studies 35: 2303-2321.

Earle, L. (2013), Stepping out of the Twilight? Assessing the Governance Implications of Land Titling and Regularization Programmes. International Journal of Urban and Regional Research

Edensor, T. and Jayne, M. 2012. Urban Theory Beyond the West: A World of Cities. London: Routledge. 
Farías, I. and Bender, T. (eds) Urban Assemblages: How Actor-Network Theory Changes Urban Studies, London: Routledge.

Ferguson, J. (1999) Expectations of Modernity: Myths and Meanings of Urban Life on the Zambian Copperbelt, Berkeley: University of California Press

Fischer, C. S. 1975. Toward a Subcultural Theory of Urbanism, American Journal of Sociology, Vol. 80, 6: 1319-1341

Friedmann, J. (1980), The territorial approach to rural development in the People's Republic of Mozambique: six discussion papers. International Journal of Urban and Regional Research, 4: 97-115

Friedmann, J. (2006), Four Theses in the Study of China's Urbanization. International Journal of Urban and Regional Research, 30: 440-451

Friedmann, J. and Wolff, W. 1982. World city formation. An agenda for research and action, International Journal of Urban and Regional Research, 6: 309-44.

Ghertner, D. A. (2011) Rule by aesthetics: World-class city making in Delhi. In Roy, A. \& A. Ong (Eds) Worlding Cities: Asian Experiments and the Art of Being Global. Oxford, Blackwel

Ginsburg, Norton S. 1955. The great city in Southeast Asia. American Journal of Sociology, 60: $455-62$

Gluckman, M. (1961) Anthropological Problems Arising from the African Industrial Revolution, in A. Southall (ed.) Social Change in Modern Africa, London, NY, Toronto: Oxford University Press, for International African Institute, Kampala, pgs. 67-82.

Goldfrank, B. and Schrank, A. 2009. Municipal Neoliberalism and Municipal Socialism: Urban Political Economy in Latin America, International Journal of Urban and Regional Research, 33, 2: 443-462. 
Goonewardena, K., Kipfer, S., Milgrom, R. and Schmid, C. (eds) 2008. Space, Difference, Everyday Life: Reading Henri Lefebvre. London: Routledge

Gordon, I. (2003) Capital Needs, Capital Growth and Global City Rhetoric in Mayor Livingstone's London Plan, paper presented at the Annual Conference of American Geographers, New Orleans, March 2003.

Granovetter, M. 1973. The Strength of Weak Ties, American Journal of Sociology, Vol. 78, 6: $1360-1380$.

Grant, R. and Nijman, J. (2004) “Re-Scaling Uneven Development in Ghana and India." Tijdschrift voor Economische en Sociale Geografie, 95 (5) 467-481.

Guggenheim, M., Deville, J. and Hrdlickova, Z. 2014. Same, Same but different: Provoking Relations, Assembling the Comparator, forthcoming in Deville, J., Guggenheim, M. and Z. Hrdličková (eds), Practising Comparison: Logics, Relations, Comparisons. Manchester: Mattering Press. Currently available at: http://www.migug.net/wpcontent/uploads/Deville-Guggenheim-Hrdlickova-Same-But-Different-copy1.pdf, accessed 28 February 2014.

Hall, P. (1966) The world cities, London: Weidenfeld and Nicholson.

Harris, A. (2008). From London to Mumbai and Back Again: Gentrification and Public Policy in Comparative Perspective. Urban Studies, 45, 12: 2407-2428.

Harris, N. (1995) Bombay in a global economy: Structural adjustment and the role of cities, Cities, 12: 175-184.

Hart (2003) Disabling Globalisation: Places of Power in Post-apartheid South Africa. Berkeley: University of California Press. 
Hasan, A., Ahmed, N., Raza, M., Saeed, A. Ahmed, D and Sarwa, M. 2013. Land ownership, control and contestation in Karachi and implications for low-income housing. London: Human Settlements Group International Institute for Environment and Development (IIED)

Hill, R.C and Kim, J. W. (2000) Global Cities and Developmental States: New York, Tokyo and Seoul, Urban Studies, 37: 2167-2195.

Hsing, Y. (2010). The Great Urban Transformation: The Politics of Land and Property in China. Oxford: Oxford University Press.

Huchzermeyer, M. (2011) Tenement Cities: From 19th Century Berlin to 21st Century Nairobi. Africa World Press, Trenton JN

Jacobs, J. M. (1996) Edge of Empire: Postcolonialism and the City, London: Routledge.

Jacobs, J. (2006) 'A geography of big things', Cultural Geographies, 13(1): 1-27.

Jacobs (2012). Commentary: Comparing Comparative Urbanisms. Urban Geography, 33, 6: 904-14.

Jazeel, T. (2014), Subaltern geographies: Geographical knowledge and postcolonial strategy. Singapore Journal of Tropical Geography, 35: 88-103.

Kantor, P. and Savitch, H.V. (2005). How to Study Comparative Urban Development Politics: A Research Note. International Journal of Urban and Regional Research, 29, 1: 135-151.

Keil, R. (ed) 2013. Suburban Constellations: Governance, Land and Infrastructure in the 21st Century. Berlin: Jovis Verlag 
Kennedy, M. D. and Smith, D. A. (1989), East central European urbanization: a political economy of the world-system perspective. International Journal of Urban and Regional Research, 13: 597-624

King, A. D. (1989), Colonialism, urbanism and the capitalist world economy. International Journal of Urban and Regional Research, 13: 1-18.

King, A. D. (1990). Global Cities: Post-Imperialism and the Internationalization of London. London: Routledge.

Lees, L., 2012. 'The geography of gentrification: Thinking through comparative urbanism', Progress in Human Geography 36, 2: 155-171.

Lefebvre, H. (2003 [1974]) The Urban Revolution. Minneapolis: University of Minnesota Press.

Le Galès, P. (2011) Urban Governance in Europe: What is Governed?, in G. Bridge and S. Watson (eds), The New Blackwell Companion to the City, Oxford: Wiley-Blackwell.

Lemanski, C. 2014. Urban theory as empirically embedded: Hybrid gentrification and downward raiding in a South African 'slum', Urban Studies,

Lin, G. C. S. (1999), State Policy and Spatial Restructuring in Post-reform China, 1978-95. International Journal of Urban and Regional Research, 23: 670-696.

Lowndes, V. 1996. Varieties of New Institutionalism: A critical appraisal. Public Administration 74: 181-197

Lowry, G. \& McCann, E. (2011) Asia in the mix: Urban form and global mobilities - Hong Kong, Vancouver, Dubai. In Aihwa Ong and Ananya Roy eds. Worlding Cities: Asian Experiments and the Art of Being Global (Oxford: Blackwell) 
Lubeck, P. and Walton, J. (1979). Urban class conflict in Africa and Latin America: comparative analyses from a world systems perspective. International Journal of Urban and Regional Research, 3, 1: 3-28.

McCann, E. and Ward, K. (2010) ‘Relationality/territoriality: Toward a conceptualization of cities in the world', Geoforum, 41: 175-184.

McCormick, D. (1999) African Enterprise Clusters and Industrialization: Theory and Reality, World Development, 27: 1531-1551.

McFarlane, C. (2010) 'The Comparative City: Knowledge, Learning, Urbanism'. International Journal of Urban and Regional Research, 34, 4: 725-742.

McFarlane, C. (2011) Assemblage and critical urbanism, City, 15(2): 204-224.

MacLeod, D.G. 2011. Urban Politics Reconsidered: Growth Machine to Post-democratic City? Urban Studies, 48: 2629-2660.

McMichael, P. (1990). Incorporating Comparison within a World-Historical Perspective: An Alternative Comparative Method. American Sociological Review, 55, 3: 385-397.

Marx, C. (2009). Conceptualising the potential of informal land markets to reduce poverty. International Development Planning Review, 31 (4), 335-353

Massey, D. 2005. For Space. London: Sage.

Massey, D., Allen, J. and Pile, S. (1999) City Worlds, London: Routledge.

Mbembe, A. and Nuttall, S. (2004) 'Writing the world from an African metropolis', Public Culture, 16(3): 347-372. 
Merrifield, A. (2013), The Urban Question under Planetary Urbanization. International Journal of Urban and Regional Research, 37: 909-922.

Mitchell, J.C. (1987) Cities, Society, and Social Perception. A Central African Perspective, Oxford: Clarendon Press.

Myers, G. (2008). Peri-urban Land Reform, Political-Economic Reform, and Urban Political Ecology in Zanzibar, Urban Geography, 29, 3: 264-288.

Myers, G. (2011) African Cities: Alternative Visions of Urban Theory and Practice. London, New York: Zed Books.

Myers, G. (2014). Unexpected Comparisons. Singapore Journal of Tropical Geography, 35, 1: 104-118.

Ndjio, B. (2009). 'Shanghai Beauties' and African Desires: Migration, Trade and Chinese Prostitution in Cameroon, European Journal of Development Research, 21(4):606-621.

Nijman, J.(2007). Place-particularity and "deep analogies": A comparative essay on Miami's rise as a world city. Urban Geography, 28, 1: 92-107.

Olds, K. (2001). Globalization and Urban Change: Capital, Labour and Pacific Rim MegaProjects. Oxford: Oxford University Press.

Olds, K. and Yeung, H. (2004) Pathways to Global City Formation: Views from the Developmental City-State of Singapore, Review of International Political Economy, 11: 489521

Parnell, S. (1997) South African cities: perspectives from the ivory towers of urban studies, Urban Studies, 34, 891-906. 
Parnell, S., Pieterse, E. and Watson, V. (2009) 'Planning for cities in the global South: An African research agenda for sustainable human settlements', Progress in Planning, 72: 233240.

Parnell, S. and Robinson, J. 2012. (re)Theorising cities from the global south: looking beyond neoliberalism, Urban Geography, 33, 4: 593-617

Payne, G. Durand-Lasserve, A. and Rakodi. C. 2007. Urban Land Titling Programmes. Legal Empowerment: A Way Out of Poverty, 3: 11-40

Peck, J., Theodore, N. and Brenner, N. (2009) 'Neoliberal urbanism: Models, moments, mutations', SAIS Review, XXIX(1): pp. 49-66.

Peck, J. and Theodore, N. (2010). Recombinant workfare, across the Americas: transnationalizing fast social policy. Geoforum, 41: 195-208.

Peck, J. and Theodore, N. (2012). Follow the policy: a distended case approach. Environment and Planning A, 44: 21-30.

Pickvance, C. 1986. Comparative urban analysis and assumptions about causality. International Journal of Urban and Regional Research, 10, 2: 162-184.

Pieterse, E. (2013) Epistemic practices of Southern Urbanism International Journal of Urban and Regional Research lecture, Annual Conference of the Association of American Geographers, April 2013. Webcast at http://www.ijurr.org/details/lecture/4803221/2013IJURR-Lecture-Epistemic-Practices-of-Southern-Urbanism.html; last accessed 23 June 2013.

Potts, D. (2010) Circular migration in Zimbabwe and contemporary sub-Saharan Africa Oxford: James Currey.

Ren, X. 2010. Urban China. Cambridge: Polity. 
Robinson, J. (2002). Global and World Cities: A view from off the map, International Journal of Urban and Regional Research, 26: 531-554.

Robinson, J. (2006) Ordinary Cities: Between Modernity and Development, London: Routledge.

Robinson, J. (2011) 'Cities in a world of cities: The comparative gesture', International Journal of Urban and Regional Research, 35: 1-23.

Robinson (2013) "Arriving at" urban policies/the urban: Traces of elsewhere in making city futures, in Söderström, O. et al. (eds) Critical Mobilities. Lausanne and London: EPFL and Routledge.

Robinson, J. 2013. The urban now: Theorising cities beyond the new., 16, 6: 659-677.

Robinson, J. (2014). New Geographies of Theorising the Urban: Putting Comparison to Work for Global Urban Studies, in S. Parnell and S. Oldfield (eds) Handbook for Cities of the Global South. London: Routledge.

Robinson, J. (2016, forthcoming). Thinking Cities through elsewhere: comparative tactics for a more global urban studies. Progress in Human Geography

Roy, A. (2003) 'Paradigms of Propertied Citizenship: Transnational Techniques of Analysis'. Urban Affairs Review, 38: 463-490.

Roy, A. (2005). Urban Informality: Towards an Epistemology of Planning. Journal of the American Planning Association, 71, 2: 147-158.

Roy, A. (2009) 'The $21^{\text {st }}$ century metropolis: New geographies of theory', Regional Studies, 43(6): 819-830. 
Roy, A. (2011) 'Conclusion: Postcolonial urbanism: Speed, hysteria, mass dreams', in A. Roy and A. Ong Worlding Cities, Oxford: Wiley-Blackwell.

Roy, A. and Ong, A. (2011) Worlding Cities, Oxford: Wiley-Blackwell.

Salskov-Iversen, D., Hansen, H.K. and Bislev, S. 2000. Governmentality, Globalization and Local Practice: Transformations of a Hegemonic Discourse. Alternatives: Global, Local, Political. 25, 2: 183-223.

Sassen, S. (1994) Cities in a world economy, Thousand Oaks, Calif: Pine Forge Press.

Savitch, H. and Kantor, P. (2004). Cities in the International Marketplace: The Political Economy of Urban Development in North America and Western Europe. Princeton: Princeton University Press.

Scott, A. and Storper, M. (2014) The nature of cities: the scope and limits of urban theory" International Journal of Urban and Regional Research, 1-16, early view.

Shatkin, G. (1998) 'Fourth world' cities in the global economy: the case of Phnom Penh, International Journal of Urban and Regional Research, 22: 378 - 393.

Simone, A. (2001), Straddling the Divides: Remaking Associational Life in the Informal African City. International Journal of Urban and Regional Research, 25: 102-117

Simone, A. (2011). The surfacing of urban life. City, 15, 3-4: 355-364.

Simone, A. (2011). City Life: From Dakar to Jakarta. London: Routledge.

Slater, D. (1978). Towards a political economy of urbanization in peripheral capitalist societies: problems of theory and method with illustrations from Latin America, International Journal of Urban and Regional Research, 2, 1: 26-52, p. 27 
Söderström, O. (2014) Cities in Relations: Trajectories of Urban Development in Hanoi and Ougadougou. Oxford: Wiley-Blackwell.

Southall, A. (1973) Introduction, in A. Southall (ed.) Urban Anthropology: Cross-Cultural Studies of Urbanization, New York: Oxford University Press, pgs 3-14.

Theodore, N. (2007). “Closed Borders, Open Markets: Day Laborers' Struggle for Economic Rights" in H. Leitner, J. Peck and E. Sheppard, eds., Contesting Neoliberalism: Urban Frontiers, New York: Guilford, pp. 250-265

Turok, I. (2014). Linking urbanisation and economic development in Africa's economic revival, In Parnell, S. and Pieterse, E. (eds) Africa's Urban Revolution. London and New York: Zed Books.

Vogel et al. (2010). Governing Global City Regions in China and the West. Progress in Planning, 73: 1-75.

Wacquant, L. 2008. Urban Outcasts: A Comparative Sociology of Advanced Marginality. Cambridge: Polity.

Waley, P. (2012) Japanese cities in Chinese perspective: towards a contextual, regional approach to comparative urbanism, Urban Geography, 33, 6:

Ward, K. (2006) 'Policies in motion', urban management and state restructuring: the translocal expansion of Business Improvement Districts'. International Journal of Urban and Regional Research 30, 54-70.

Ward, K. (2010) Towards a relational comparative approach to the study of cities. Progress in Human Geography 34: 471-487

Watson, V. (2009) 'Seeing from the south: Refocusing urban planning on the globe's central urban issues', Urban Studies, 46(11): 2259-2275. 
Wirth, L. (1938).Urbanism as a Way of Life, The American Journal of Sociology, Vol. 44, 1: 124

Wirth, J. D. and Jones, R. L. (eds) 1978. Manchester and São Paulo: Problems of Rapid Urban Growth. Stanford: Stanford University Press.

Wu, F. (2004), Urban poverty and marginalization under market transition: the case of Chinese cities. International Journal of Urban and Regional Research, 28: 401-423

Wu, F. (2010) How Neoliberal is China's Reform? The Origins of Change during Transition, Eurasian Geography and Economics, 51, 5: 619-631.

Yiftachel, O. (2009) Theorizing 'Gray Space': the Coming of Urban Apartheid?', Planning Theory, 8: 1: 88-100. 
' In this light, the attempt to carve out a distinction between territorially defined urban processes (putatively those of agglomeration and an urban "land nexus"), and wider social and economic dynamics, as Scott and Storper (2014) seek to do, is one which is quite at odds with the subtlety and complexity of work grappling with globalisation and cities, informed by analyses of urban spatialities. Interpretations of the urban have the resources to work across this false dichotomy in interesting ways after: the spatial analytics of Henri Lefebvre (1974) indicating the urban as quintessentially a site of assemblage (producing both the possibilities of centrality and difference) ; David Harvey's analyses of the importance of attending to wider connections shaped by transformations in time-space; and Doreen Massey's insistence on the multiple trajectories producing space, as therefore already global. Rather than suggesting it could describe "anywhere on earth", Scott and Storper might find it useful to take a little more time over my summary (and quite conventional) characterisation of urban space as "assemblage, multiplicity, interconnection" for these reflect very precise analytical trajectories trying to get to grips with the spatiality of the urban. The idea that what is in the urban, profoundly shaped by the distinctive spatialities of the urban, is somehow not-urban is to raise some very 1980 s style debates pace Saunders and Castells, which have been so very neatly reconfigured in the interesting ongoing work of spatial theorists (Massey, 2005; Goonewardena et al, 2008).

ii Myfanwy Taylor develops this point in her UCL-based PhD research on alternative economies in London.

iii Significantly, Storper himself observed in 1989 the need for a "close re-evaluation of received concepts and assumptions"(p. 441) in the wake of the global crisis of Fordist modes of production and regulation.

iv I offer here a different array of comparative tactics from that which was set out by Charles Tilly and, following him, Neil Brenner. They proposed: Variation-finding, encompassing, and individualising methods (see Robinson, 2011 for a review; and McMichael (1991) for a very useful paper on encompassing approaches). The challenge of thinking across diverse and profoundly interconnected urban outcomes (see Robinson, 2014) brings these strategies much closer to each other; and the possibility of new analyses of the relationship between specific outcomes (variation as singularities, for example) draws encompassing approaches towards both variation finding and individualising approaches. I have found it helpful to adopt a different taxonomy, more specific to the conundrums posed by the urban as an object of enquiry. 